\title{
INVESTIGATIONS ON DISPOSAL OF LOW-CALORIFIC LANDFILL GASES BY A SMALL SCALE FLUIDISED BUBBLING BED COMBUSTION PLANT
}

\author{
D. STEINBRECHT ${ }^{1 *}$ \\ H.J. WOLFF ${ }^{1}$ \\ R. MATZMOHR ${ }^{1}$ \\ A. NASSOUR ${ }^{1}$ \\ H. DIDIK ${ }^{2}$
}

Received: $14 / 11 / 05$

Accepted: 29/03/06

\author{
${ }^{1}$ University of Rostock \\ Germany, Environmental Engineering \\ ${ }^{2}$ LUNG Landesamt für Umwelt \\ Naturschutz und Geologie, Güstrow, Germany
}

*to whom all correspondence should be addressed: e-mail: dieter.steinbrecht@uni-rostock.de

\begin{abstract}
Poor landfill gases cannot be used to drive gas engines or be burnt in gas flares. This follows why the combustion flame front velocity for poor gases becomes very low. From this moment the non-flammable poor landfill gases are polluting the environment. An energetical utilisation of very poor landfill gases is of ecological interest and is also an important contribution for climate protection. A feasible solution must be found.

In our University lab we are using a Fluidised Bubbling Bed Combustion (SFBC) plant with $200 \mathrm{~kW}$ completed by heat exchangers for pre-heating the combustion air as well the combustion gas. In the past this SFBC-principle had successfully been applied to a thermal utilization of very different wastes. Using this principle we are able to recover the energy content of very poor landfill gases down to a concentration below the lower explosion limit. The fluidised red hot inertia bed material at a temperature of $850^{\circ} \mathrm{C}$ is an excellent ignition source to run the process at constant parameters within legal limits. Therefore we have very low pollutant emission levels.
\end{abstract}

Using a developed mathematical SFBC-model we theoretically investigated the lowest possibly methane concentration limits under given pre-conditions as well as fluidised bed temperature level, fluidisation air and fuel gas temperatures, necessary oxygen concentration level. Following to these model investigations we realized their experi-mental verification in our $200 \mathrm{~kW}$ lab SFBC testing plant in a wide-spread plant load range. These lab tests had very successful results. The possible SFBC operation conditions have been estimated.

Based on these results we engineered by the help of industrial partners a real SFBC plant installed on a closed landfill in Mecklenburg - Western Pomerania, $65 \mathrm{~km}$ far from our University lab. Using these plant we dispose there real very poor landfill gas. The landfill gas is poor enough to avoid a further operation of a common gas flare. The automatically operated SFBC process is running at $850{ }^{\circ} \mathrm{C}$ without any technical interruptions since one year. At the moment the maintenance rate is 3 weeks. The plant is supervised by data remote control. The contribution will compare the lab test results with the results of the real existing plant.

If the poor landfill gas flow is strong enough the SFBC produces enough energy e.g. to drive a steam cycle or a gas turbine externally fired by the SFBC that generates electrical power. In this case the necessary power equipment has to be added to the SFBC plant.

KEYWORDS: stationary fluidised bubbling bed, flameless fluidised bed combustion, low calorific gas, landfill gas 


\section{INTRODUCTION}

Under the conditions of a landfill the organic material disposed there leads to the generation of methane. The landfill acts similar to a bio-reactor. The generation of methane is a long lasting process that can work for several decades up to more than one hundred years.

Landfill gas consists of the following main components

- $\quad$ inflammable methane and

- non flammable carbon dioxide and nitrogen.

At the beginning of the gas production period landfill gas can be utilized energetically e.g. in cogeneration plants, realized by gas engines or gas turbines. Later on it can be burnt and disposed by gas flares. The landfill gas quality (characterized by methane concentration) as well as the gas mass flow decrease with running degassing time. An operation of gas engines, gas turbines or gas burners (in flares) becomes impossible if the actual gas concentration remains under their individual limits.

Methane containing landfill residue gas is highly relevant to influencing climate. In case of no utilisation this gas is emitted into the atmosphere during a long period of time. A biological disintegration of methane to carbon dioxide and water exclusively by passing the residue gas through organic material cannot solve the problem.

\section{A TECHNICAL ANSWER TO SOLVE THE PROBLEM OF LANDFILL RESIDUE GAS}

It is proposed to dispose landfill residue gases by a small scale fluidised bed combustion plant (see Figure 1).



Figure 1. Schematic view of a SFBC

A small-scale fluidised bubbling bed combustion plant (SFBC) is able to burn poor landfill residue gases characterized by remarkably lower methane concentrations than the known limits. The SFBC can safely be operated in a self running continuously working process characterized by high specific thermal power and operated without any additional fuel input. Using the solution proposed it is possible to economize gas flares in every case.

Construction and operational conditions of a SFBC used for thermal utilization of poor landfill residue gases are demonstrated in detail in [1], [2], [3], [4], [5], [6]. There first theoretical results supported by the SFBC model used as well as experimental results related to the behaviour of the SFBC in dependency of methane concentration are presented. 
The heat generated within the process can be used for an air pre-heating as well as a fuel gas pre-heating. If there is enough landfill residue gas available it is possible to remove enough energy from the process to drive a steam cycle, an externally fired gas turbine or an ORC process. A self sufficient process is possible, in minimum. Excess energy is able to be fed into the public supply mains.

If extremely poor gases have to be used it is to be kept in mind that a quasi-adiabatic combustion within the SFBC is necessary.

\section{RESULTS OF MODEL INVESTIGATIONS}

Theoretically, a combustion of landfill residue gas with low methane concentration is possible if the reaction temperature level is above the methane ignition temperature $\left(t_{\text {ignition }} \sim 600^{\circ} \mathrm{C}\right)$ and if there is enough oxygen available. This can be calculated by using energy balances.

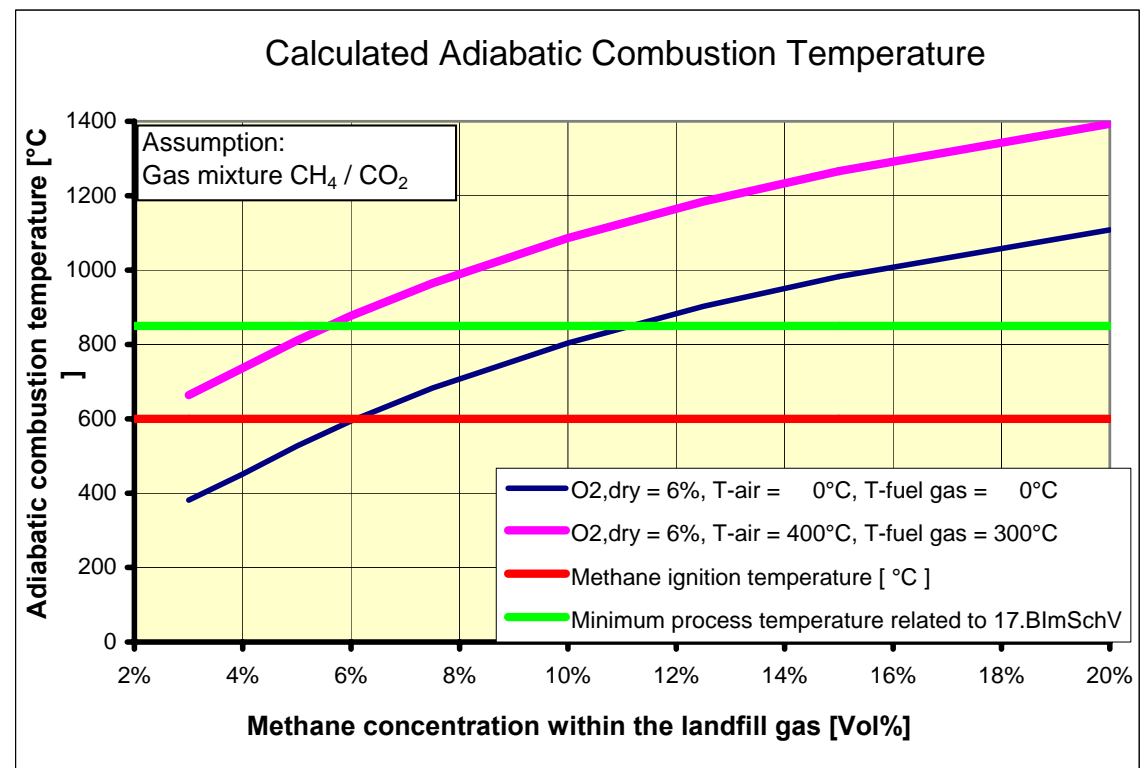

Figure 2. Results of model investigations related to the possible methane concentrations for an SFBC use of very poor landfill residue gases.

For "weak" fuel gases an energy input into the SFBC is not only possible by the fuel gas. The energy input is possible to be increased by an air and/or gas pre-heating. A pre-heating of extremely poor methane fuel gas becomes more effective than a pre-heating of the combustion air at the same temperature.

If an air and fuel gas pre-heating $\left(t_{\text {air }}=400^{\circ} \mathrm{C}, t_{\text {fuel gas }}=300^{\circ} \mathrm{C}\right.$ ) by heat de-coupling from the process is possible then the lowest methane concentration for an SFBC use can be achieved at $5 \ldots 6$ vol\% methane (see Figure 2) at high specific plant capacity.

\section{TEST RESULTS}

The SFBC plant used for the poor landfill gas tests is characterized by two heat exchangers for both an air-preheating as well as a fuel gas pre-heating. A process controller records all process data and guarantees constant SFBC process temperatures (e.g. $\mathrm{T}_{\mathrm{SFBC}}=855^{\circ} \mathrm{C} \pm 5 \mathrm{~K}$ = reaction temperature) by varying the fuel gas volume flow.

The investigations discussed in [3] related to the influence of the methane concentration on the operation of the plant have been supposed by tests with „synthetic“ landfill residue gas (methane / nitrogen-mixture). The model investigations using "weak" landfill residue gas (8 vol\% methane, 92 vol\% nitrogen) have been verified at the SFBC mentioned above (see Figure 3). For the given conditions $\left(T_{\mathrm{SFBC}}=855^{\circ} \mathrm{C} \pm 5 \mathrm{~K}\right.$ at $8 \mathrm{vol} \%$ methane) is a sufficient oxygen concentration available for a qualified combustion process. 


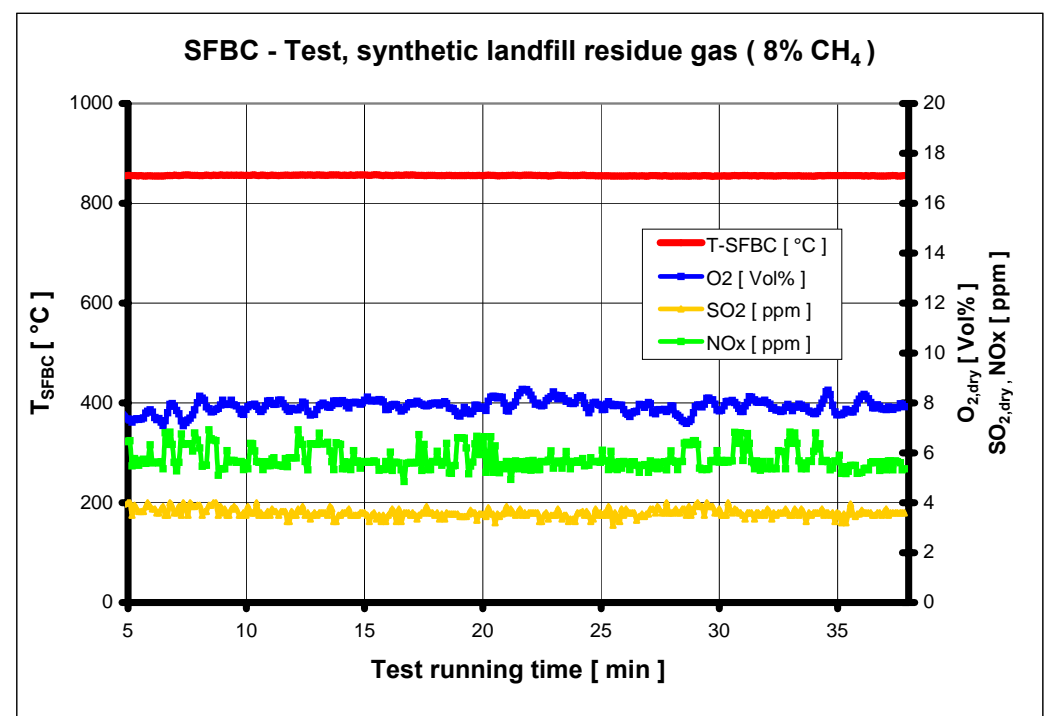

Figure 3. Plot of a SFBC test using synthetic poor landfill residue fuel gas, 8 vol\% methane

The results of model predictions have been confirmed by the tests. The SFBC can safely be operated both in wide-spread concentration and mass flow regions. In comparison of the synthetic gas mixtures to real landfill gases can the different fuel gas properties properly be described by the model.

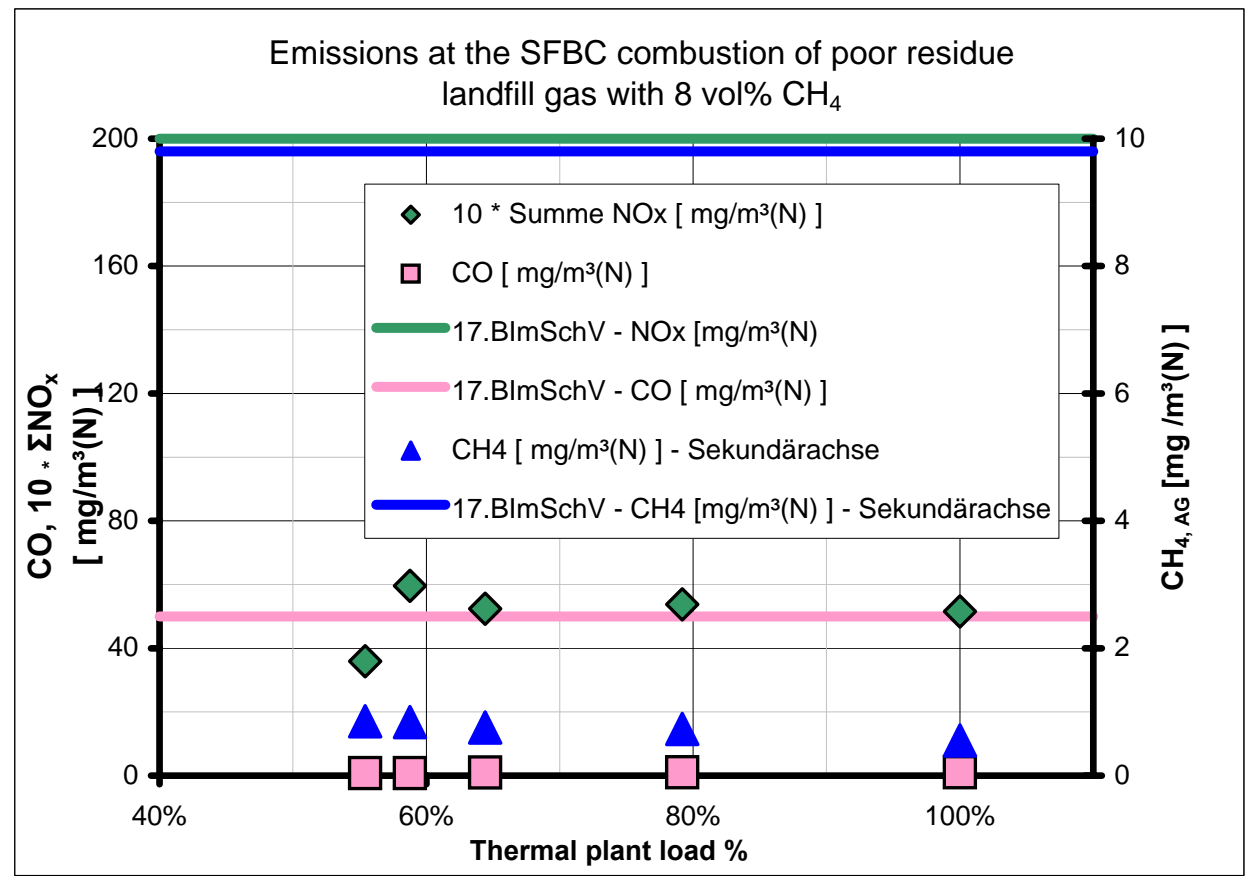

Figure 4. SFBC flue gas emissions burning landfill gas, 8 vol\% methane

The flue gas emissions during the test periods at $\mathrm{T}_{\mathrm{SFBC}}=855^{\circ} \mathrm{C} \pm 5 \mathrm{~K}$ remained obviously below the limits of the German Emission Laws (17. BImSchV), Figure 4.

With aspect to the later SFBC operation on a landfill the behaviour of the SFBC after an unforeseeable plant stop was tested. The problem of a safe "warm" plant re-start was tested. In result of the tests permitted temperature ranges for a safe re-ignition of the poor landfill gas could be defined. The automatic process control enables a self-acting SFBC re-start. 


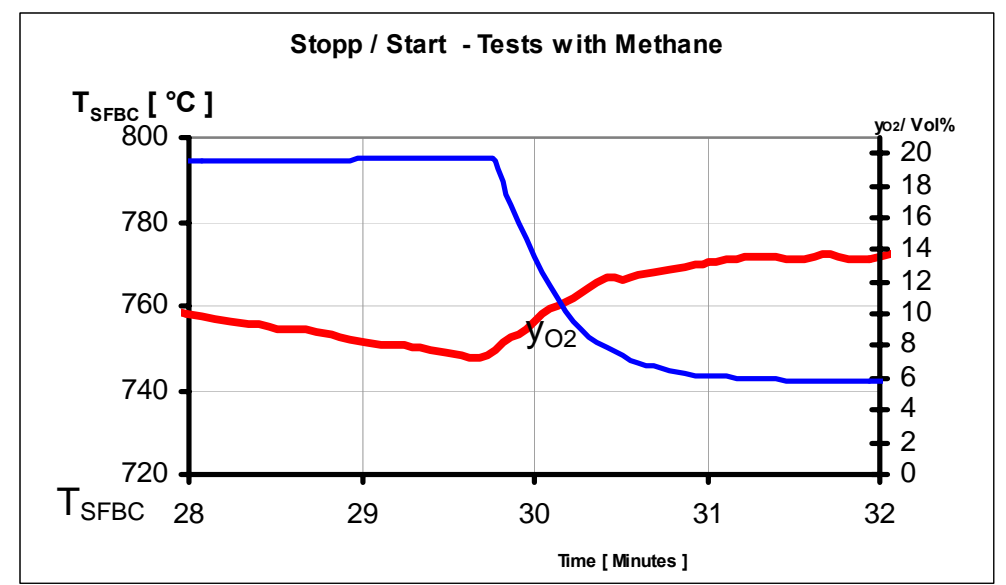

Figure 5. Successful SFBC stopp $/$ Re-start Test at $\mathrm{T}_{\mathrm{SFBC}}=750^{\circ} \mathrm{C}$

\section{POOR LANDFILL GAS SFBC OPERATED ON A LANDFILL AT MECKLENBURG- WESTERN POMERANIA}

In 2004 a SFBC with $100 \mathrm{~kW}$ thermal power was erected on a closed landfill at Mecklenburg - Western Pomerania, Figure 5 (right side). Up to this moment there was a common gas flare in use (left side), but the very poor gas quality caused longer operation interruption periods. The common gas flare operation had been shut down. The flare is preserved and demounted now.

The SFBC plant successfully had absolved a licensing procedure according to the German 17.BImSchV. The SFBC is automatically operated with process data record and is remote controlled. The plant automatically generates safe operational regimes inclusive "warm" plant re-starts. By remote control it is possible to change the plant load or to put the plant out of operation.

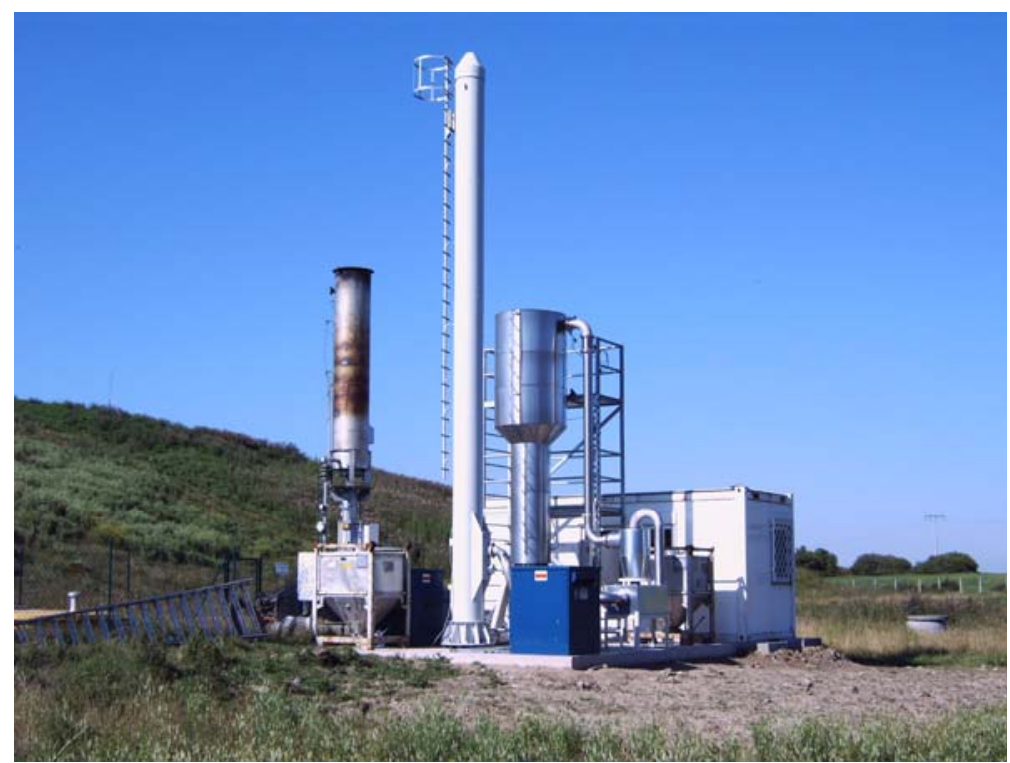

Figure 6. Construction of the SFBC on the landfill at Mecklenburg-Western Pomerania

Figure 7 and figure 8 present relevant data records during a supervised 72 hours plant test run after setting the SFBC into operation. 


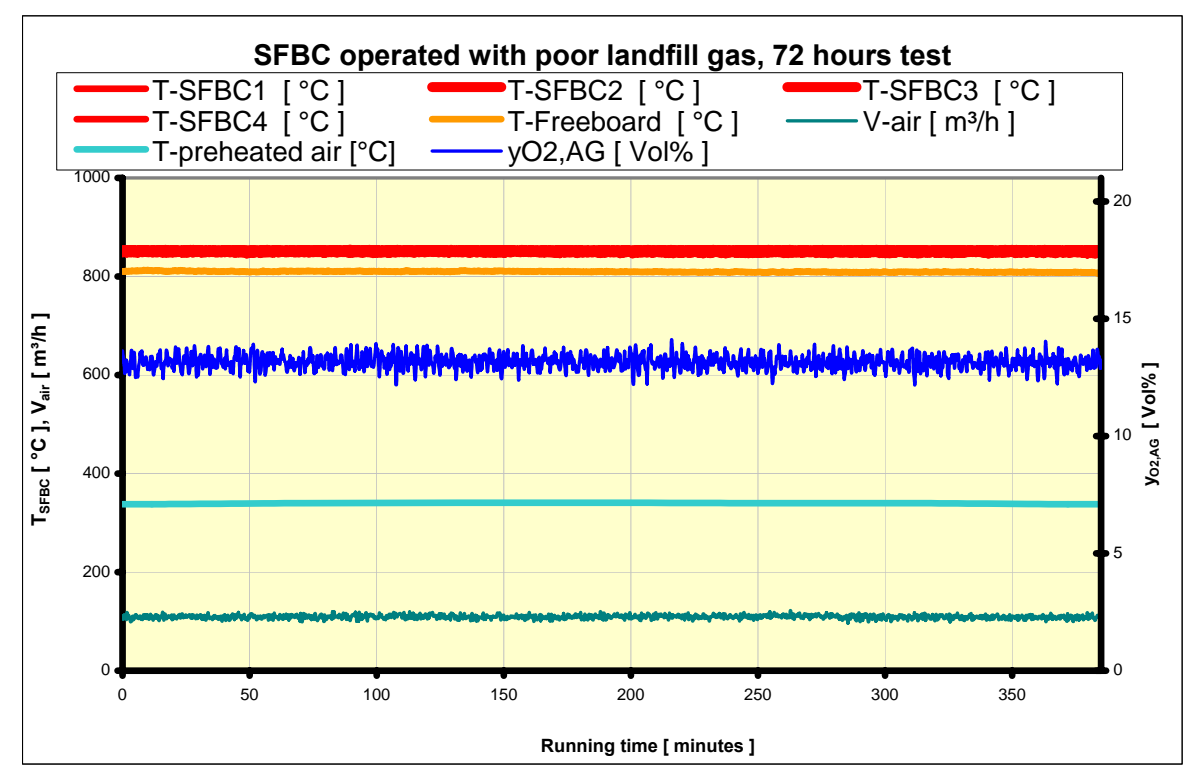

Figure 7. Data record of a part of the 72-hours test run of the landfill gas SFBC



Figure 8. Mean values of the des 72-hours test run of the landfill gas SFBC

The automatically operated open-air SFBC plant is characterized by very constant bed temperatures and emissions. The time of the day (sunshine) as well as weather conditions (wind, storm, clouds) influence the heat losses of the system. This is visible by observing the freeboard temperatures (see Figure 8).

Figure 9 and table 1 present results of emission records at the "normal" load point of the SFBC plant. The emission situation and fluidised bed temperatures do not change if fluidisation air throughput, that means the thermal plant power situation, is changed. The experimental results underline that the SFBC operation with poor residue landfill gases is possible without any emission and operation problems.

The SFBC plant operation is characterized by a high reliability. The operation time was more than 7400 hours for the first one-year period. In this time could several changes in landfill gas quality be observed. These changes had no influence on the "normal" operation of the SFBC. There was only a very low mechanical wear of the inertia bed material. At the moment the maintenance rate is 3 weeks with the aim of 4 weeks. 


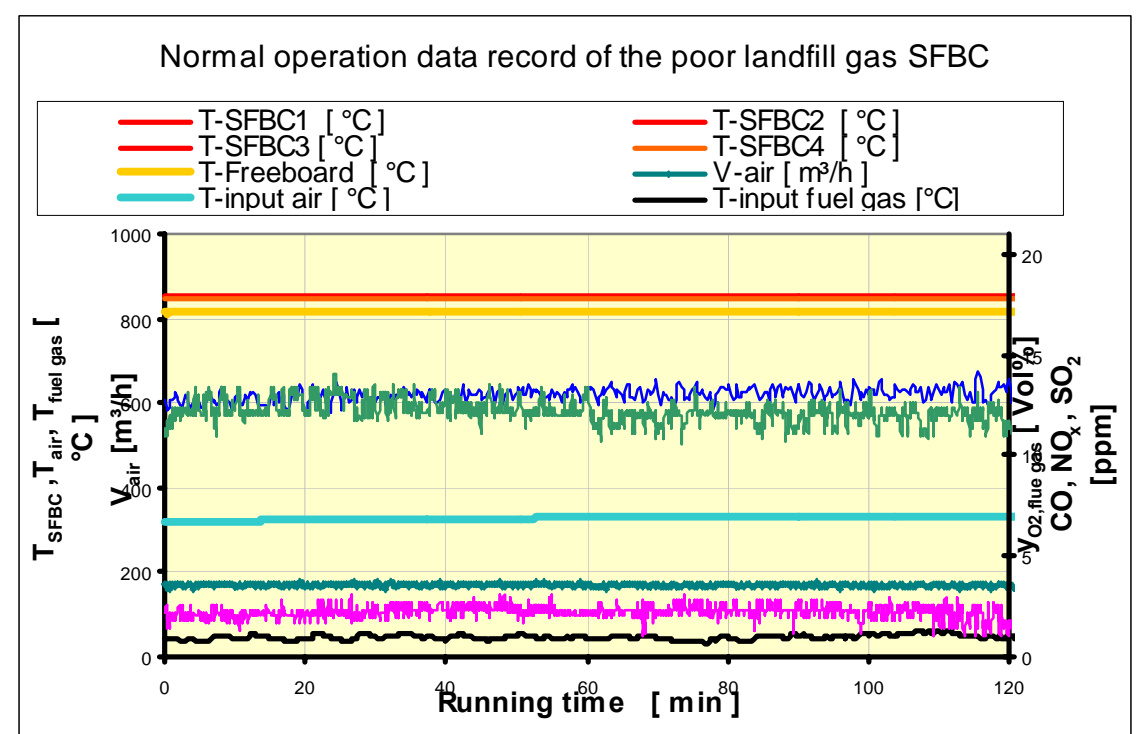

Figure 9. Data record of the normal operation regime of the landfill gas SFBC

Table 1. Overview of the mean values of a 120-minutes data record Mean values during measurements (1):

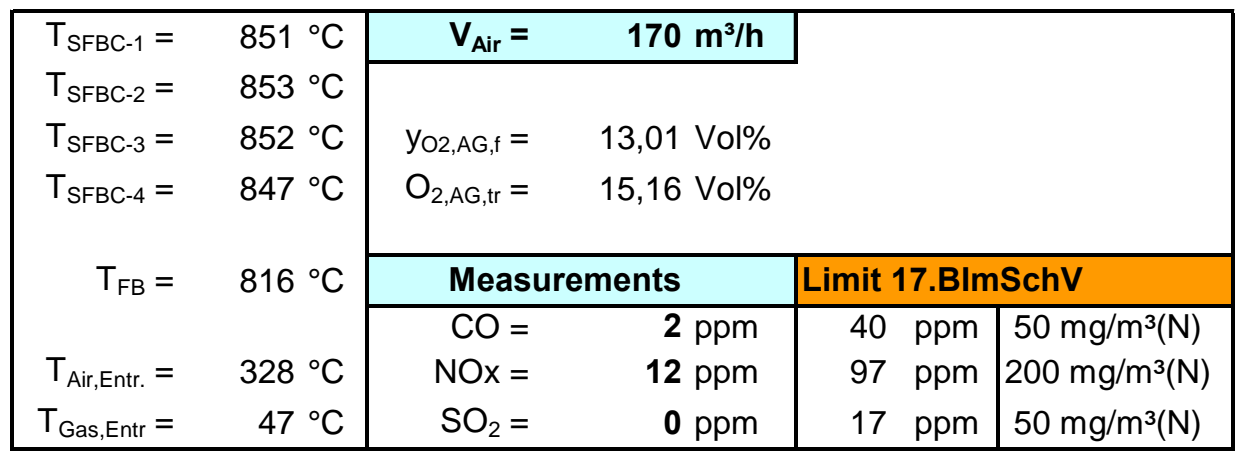

Figure 10 presents the screen of the Remote Control Computer, presenting the actual data information:



Figure 10. Screen of the Remote Control Computer 
The very good emission values of the SFBC operated with very poor landfill gas had been confirmed by emission measurements of a licensed measurement firm in June, 2005, see Figure 11.

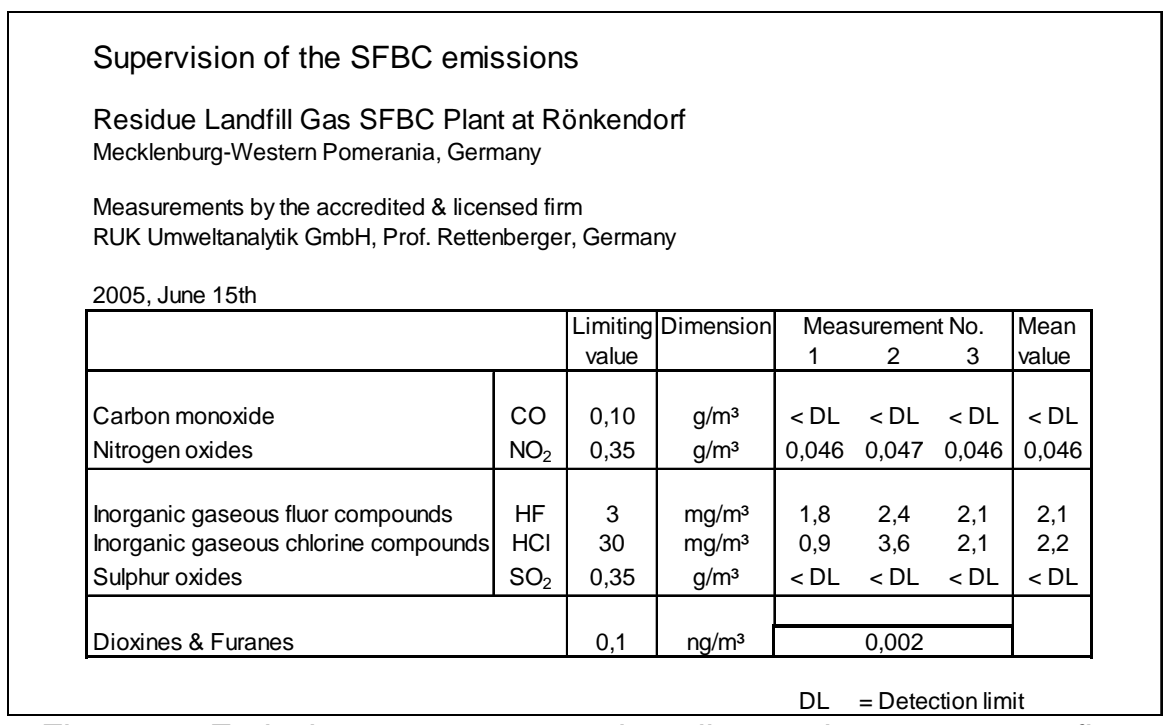

Figure 11. Emission measurements by a licensed measurement firm

\section{SUMMARY}

The SFBC principle used for a disposal of low-calorific landfill gases

- Is safe in a remote controlled operation

- $\quad$ Saves a gas flare completely

- It enables a self sufficient plant operation using a steam cycle or an ORC cycle if enough gas is available. In case of great poor landfill gas volumes the excess energy is able to be fed into the public supply mains.

- Elongates the supervised degassing time of a methane containing landfill gases for a great period of time

- $\quad$ Avoids environmental pollutions and minimizes safety-relevant emissions caused by gassing landfills.

- Makes a remarkable contribution for climate protection

- Needs politically founded conditions

- Is useful seen from technical and economical standpoints

\section{ACKNOWLEDGEMENT:}

The authors have to thank the "Landesamt für Umwelt, Naturschutz und Geologie" (LUNG) in Güstrow, Mecklenburg - Western Pomerania, Germany, for the great interest and for financial support. The authors have to thank the engineering firms ES+S Energy Systems \& Solutions, Rostock, Germany, and IMG Ingenieurtechnik Rostock, Germany for engineering and realization.

\section{REFERENCES}

1. Steinbrecht D., Matzmohr R., Backhaus E., Wolff H.-J., Lange F. and Sperling B. (2002) Deponie- Restgasverwertung in Mecklenburg-Vorpommern, Forschungsbericht der Universität Rostock im Auftrage des Landesamtes für Umwelt, Naturschutz und Geologie MecklenburgVorpommern, Güstrow.

2. Steinbrecht D. and Geier H. (1999), Verfahren zur thermischen Verwertung und Entsorgung von Deponiegas mit hohen bis geringen Methankonzentrationen, Patent Aktenzeichen: DE $P$ 19939390.7 vom 19.08.1999. 
3. Steinbrecht D., Matzmohr R., Wolff H.J. and Didik H. (2003) Entsorgung von heizwertarmen Deponie - Restgasen mit einer Wirbelschichtfeuerung, Fachtagung "Stillegung und Nachsorge von-Deponien - Deponiegas“, Trierer Berichte zur Abfallwirtschaft, 14, 245-255

4. Steinbrecht D., Matzmohr R., Wolff H.J. and Didik H. (2003) "Entsorgung von heizwertarmen Deponie - Restgasen mit einer Wirbelschichtfeuerung“, Vortrag zum Seminar Abfallwirtschaft an der Fachhochschule Güstrow, 3.Juni 2003, Vortrag zum „6. Dialog Abfallwirtschaft Mecklenburg - Vorpommern an der Universität Rostock“, 3. Juli 2003

5. Matzmohr R., Wolff H.J. and Steinbrecht D. (2004) Emissionsarme Verbrennung von stark schwefelhaltigem Petrolkoks in der Stationären Wirbelschichtfeuerung DN 400 am Institut für Energie- und Umwelttechnik der Universität Rostock, Vortrag GVC / Dechema - Kolloquium 23.04.2004 Berlin

6. Steinbrecht D., Wolff H.J., Matzmohr R. and Nassour A. (2004) ,Entsorgung von heizwertarmen Deponie-Restgasen mit einer Wirbelschichtfeuerung, Vortrag zur DEPOTECH 2004, Leoben, Österreich, 24. bis 26. November 2004 Tagungsband, 124/132

7. Steinbrecht D., Wolff H.J., Matzmohr R., Nassour, A. and Didik H. (2005) ,Untersuchungen zur Entsorgung von heizwertarmen Deponie-Restgasen mit einer Wirbelschichtfeuerung, Vortrag zur Tagung Stillegung und Nachsorge von Deponien - Schwerpunkt Deponiegas, Trier 2005 in: Rettenberger / Stegmann, Trierer Berichte zur Abfallwirtschaft Band 16 (2005), S. 135-146 